\title{
A DEFESA SIMBÓLICA E POLÍTICA DO TERRITÓRIO INDÍGENA: CUETZALAN, PUEBLA (MÉXICO)
}

Pierre Beaucage - Université de Montréal, Québec, Canadá Taller de Tradición Oral del CEPEC, San Miguel Tzinacapan, Cuetzalan, Puebla, México

Existe uma concepção estreita da defesa territorial que a limita aos enfrentamentos abertos entre a população local e as forças externas. Omite-se, então, que os próprios povos camponeses e indígenas, no processo de produção de sua subsistência, apropriam-se material e simbolicamente de um determinado meio ambiente até transformá-lo em seu território. Essa apropriação constituirá precisamente a base de uma ação política posterior. É o que queremos mostrar aqui, no caso dos Nahua de Cuetzalan, fundamentados por um estudo prolongado na região. Utilizaremos o conceito de território no sentido utilizado pelos atores locais, ou seja " "a integração do espaço com a cultura" (CORDETIC 2010:1).

Consideramos que houve três grandes épocas na construção do território que hoje constitui o município de Cuetzalan. A primeira época corresponde ao período pré-colonial e teve fim com as terríveis epidemias que se seguiram à conquista espanhola, destruindo o pequeno povoado de Quetzalcoatl, situado próximo à sede do município atual. A segunda época se estendeu da fundação do povoado como "república de índios", em meados do século XVI, até as leis da Reforma (1856). Logo depois, desmantela-se o común de naturales, forma coletiva de posse da terra, e começa a terceira época, em que se impõe a propriedade privada, majoritariamente de minifúndios, que permanece até hoje. Durante esse terceiro período, a população indígena construiu definitivamente o ecossistema atual, formou a identidade cuetzalteca e a representação do território. Os indígenas adaptaram sua forma de vida à transformação radical que representou a privatização da terra, em um período de rápido aumento demográfico (Beaucage e Taller de Tradición Oral, 2013, cap.2). Um elemento-chave foi a expansão da cafeicultura ao longo do século XX. O cafezal tradicional indígena, longe de ser um monocultivo destruidor do meio ambiente, como pode ocorrer nas grandes propriedades cafeeiras, desenvolveu-se como um policultivo arbóreo que representa, junto à milpa, uma adaptação particularmente apropriada ao ambiente tropical de montanha que caracteriza a zona (Taller de Tradición Oral e Beaucage, 1997a).

Nossas investigações conjuntas cobriram a área de etnobiologia, assim como as de etno-história e toponímia, que mais nos interessam aqui. O estudo etno-histórico teve duas vertentes: uma pesquisa de campo sobre a memória histórica e uma análise de fontes escritas em nível local, regional e nacional (Taller de Tradición Oral, 1994; Beaucage, 1995; Jáimez, Ramíreze Valderrama, 1992). A pesquisa sobre toponímia em San Miguel Tzinacapan produziu centenas de nomes de lugares, com descrições detalhadas de seu ambiente natural e social. Essas investigações revelaram um povo, os Nahua de Cuetzalan, profundamente enraizado em um território específico, conhecedor de suas características 
ecológicas e de seus recursos. Séculos de presença foram traduzidos por uma apropriação em três níveis. Em primeiro lugar, em nível material, a apropriação aconteceu por meio de uma exploração diferenciada, que combina a agricultura com a arboricultura, a criação de animais, a caça, a pesca e a coleta de produtos silvestres. Em segundo lugar, ela ocorreu, e ainda ocorre, em nível político, ou seja, lutando por sua autonomia, tanto através dos mecanismos jurídicolegais como pela ação direta. Em terceiro lugar, apropriaram-se em nível simbólico de seu território, nomeando cada parcela e associando a elas sua memória histórica e suas crenças.

Essa tripla apropriação estabeleceu uma identidade que se manifestou em circunstâncias críticas. A memória coletiva registrou os atropelos cometidos pelas tropas francesas de Intervenção, no século XIX, e os abusos de uns bandoleiros autonomeados "villistas" durante a Revolução; recorda também as rebeliões vitoriosas dos antepassados (Taller de Tradición Oral, 1994). Essa identidade assume toda sua importância na conjuntura atual, quando poderosos interesses cobiçam o território cuetzalteco, assim como o restante da Serra Norte de Puebla e muitos territórios indígenas do México e da América Latina. Essas áreas são atrativas devido às suas riquezas minerais, florestais e hidroelétricas, ou devido ao seu potencial turístico. O presente trabalho foi precisamente inspirado pela formação, há três anos, do Comitê de Ordenamento Ecológico Territorial Integral de Cuetzalan (CORDETIC) . Formado pelas principais organizações sociais do município, o Comitê quis opor sua própria visão de desenvolvimento da região a um megaprojeto de infraestrutura turística. Atualmente, como veremos mais adiante, seu principal componente popular, a União de Cooperativas Tosepan Titataniske, integrou-se a um amplo movimento regional, o Conselho Tiyat Tlalli, que agrupa comunidades e organizações da serra alta e da serra baixa em oposição a uma avalanche de projetos minerários ehidroelétricos.

Esse artigo tem duas grandes partes. Na primeira, após caracterizar brevemente o meio ambiente da Serra Norte de Puebla, apresentaremos, com base em nossas investigações etno-históricas, as principais etapas da formação do território e da identidade indígena que acabamos de esboçar. Na segunda parte, iremos enfatizar as práticas e concepções territoriais nahua, incluindo a toponímia, comoreveladoras de sua apropriaçãomaterial, política esimbólica. Nosso estudo pretende ser uma colaboração aos esforços daqueles que lutam para que, na região, prevaleça o equilíbrio ecológico e a autonomia de seus habitantes, em grande maioria indígenas, sobre os interesses das transnacionais.

\section{O MEIO AMBIENTE DA SERRA}

A região administrativa conhecida como "Serra Norte de Puebla" está localizada a uns $20^{\circ}$ de latitude norte (limite do trópico). Os ventos predominantes são os alísios, que sopram a partir do Atlântico na maior parte do ano, com "nortes" tormentosos que ocorrem entre agosto e dezembro, e raros ventos do Pacífico. A área contêm quatro zonas naturais diferentes, em função da altitude, do relevo e do regime de ventos.

a) O planalto central, com altitudes superiores a 2.000 metros, ocupa a parte sudoeste. É frio e seco (em parte semiárido), pelo "efeito de cortina" da serra vizinha. As precipitações anuais são de uns $1.000 \mathrm{~mm}$, às vezes menos, concentradas entre maio e outubro, e geadas em dezembro e janeiro. A vegetação natural é de cactáceas, agaves e 
arbustos, com vestígios de florestas de pinheiros e carvalhos. O terreno é predominantemente plano; são cultivados grãos e criado gado. Sua população atual, pouco densa, é majoritariamente mestiça.

b) A Serra Madre Oriental constitui essencialmente uma queda abrupta do altiplano ao mar e tem dois níveis bem diferenciados ecologicamente.Aserra alta(1.500a 2.200metros), muitoacidentada, é fria eúmida comuma precipitação anual de $1.500 \mathrm{~mm}$ a $2.000 \mathrm{~mm}$ aproximadamente: as fortes chuvas de verão (junho a agosto) se prolongam com chuviscos até janeiro. Originalmente estava coberta por uma mata típica de terras altas com carvalhos (auat, Quercus spp.) e pinheiros (okot, Pinus patula Schlecht et Cham.) e com outras espécies como liquidâmbar (Liquidambar styraciflua L.). Atualmente, restam somente vestígios dessa flora, em canhadas profundas ou no cume de montanhas, posto que a maior parte da terra foi desmatada para a agricultura e a pastagem. A população é mais densa do que no altiplano e majoritariamente de origem Nahua, ainda que a aculturação seja muito importante (adoção generalizada do espanhol e da indumentária mestiça).

c) A serra baixa (entre 500 e 1.500 metros), onde se situa Cuetzalan, é temperada e extremamente úmida. Sua frondosa vegetação se deve à abundância de chuvas de verão (junho a agosto) seguida de garoa e neblina até fevereiro. A precipitação total oscila entre 2.000 e 4.000 mm anuais, sendo março, abril e maio os meses com menos chuva. Mesmo na primavera, mais seca, há aguaceiros frequentes. Avegetação natural é um monte alto tropical de montanha, incluindo o mogno (ayakachkuouit, Swietenia macrophylla King), o cedro (tiokuouit, Cedrela odorata L.) e os sapotizeiros (p. ej. kuoujtsapot, Pouteria sapota [Jacq] H.B. Moore \& Stern), cujos troncos servem de apoio a um denso tecido de cipós e trepadeiras. As samambaias são abundantes, em particular as espécies arborescentes (p. ex. pesmakuouit, Cyathea mexicana Schlecht). Onde penetra luz suficiente no arvoredo, o solo se cobre de plantas herbáceas, algumas de grande tamanho como a helicônia (chamakijisuat, Heliconia bihai L.). Nas barrancas, encontram-se palmeiras e bambus, enquanto nas alturas de mais de mil metros há algumas espécies vegetais caducifólias típicas de montanhas altas, pinos, carvalhos e ilites (ilit, Alnus acuminata [Schlecht] Furlow).

$\mathrm{Na}$ atualidade, na serra baixa, somente em alguns locais de dificil acesso podem ser encontradas as espécies vegetais originarias . A população é extremamente densa (250 pessoas por $\left.\mathrm{km}^{2}\right)$ e em sua maioria indígena: Nahua a oeste, sul e leste; Totonaco ao centro. Os campesinos cultivam milho (taol, Zea mays L..), feijão (et, Phaseolus vulgaris L.), café (kajfenkuouit, Coffea arabica L.), pimenta (mimientakuouit, Pimenta dioica [L.] Merrill), frutas como laranja e sapoti e um pouco de cana-de-açúcar (tsopekouat, Saccharum officinarum L.) para a venda (Beaucage, 1974) . O município de Cuetzalan, onde está San Miguel Tzinacapan - a comunidade Nahua de que trataremos principalmente -, encontra-se nesse ecossistema, e se estende de sul a norte, descendo de 1.200 a 500 metros sob o nível do mar.

d) Mais abaixo, ao norte e ao leste, a planície costeira (500 metros abaixo do nível do mar) é quente e úmida (1.500 a $2.000 \mathrm{~mm}$ de precipitação anual). Era uma zona de floresta tropical e de planícies, que deu lugar a grandes pastos, a alguns milharais e a plantações de baunilha e frutas cítricas. Sua população é menos densa e, sobretudo, mestiça, exceto no centro-norte de Veracruz onde predominam os Totonaco. 
examinar o processo histórico de interação, cooperação e conflito entre indígenas (maseualmej) e mestiços (koyomej), nesse meio bem particular da montanha baixa.

\section{A SERRA NORTE DE PUEBLA NO PERÍODO PRÉ-COLONIAL}

As relações geográficas do final do século XVI já mencionavam a serra baixa. Como acontece hoje, os Nahua e Totonaco que a habitavam cultivavam o milho e outras culturas: pimentas, feijões, abóboras e quelites (González, 1905: 129-130). A criação de aves, a pesca e a caça eram recursos adicionais para a sua alimentação e, também, aponta-se que "eles mesmos se curam com muitas ervas que crescem nas montanhas e nas barrancas" (ibid.). Além de trabalhar para os senhores locais, tinham que pagar tributo aos astecas: os habitantes da serra alta contribuíam com resina de liquidâmbar e peles; os da serra baixa davam tecidos feitos com algodão local (Gossypium hirsutum L.) e penas preciosas (cuetzalli, daí o nome de "Cuetzalan"), enquanto os habitantes das terras baixas vizinhas tinham que enviar pescado salgado, mel, sal e pimentas (Beaucage, 1974: 31-32). Aúnica menção de comércio que faz o cronista se refere ao sal que "eles trazem de Tahuacan, cidade que se encontra a quarenta léguas daqui" (González, 1905: 130). Os dados disponíveis demonstram que os indígenas exploravam os diferentes recursos da terra para cultivos diversificados, os rios para a pesca e o campo para a caça e a coleta, como na época atual.

\section{O PERÍODO COLONIAL E O SEGUNDO ORDENAMENTO TERRITORIAL}

Após a conquista, os indígenas da Serra, como no resto da Mesoamérica e dos Andes, foram submetidos ao duro regime de encomienda . Eram "encomendados" a um conquistador que podia utilizar sua força de trabalho à vontade e devia incentivar sua conversão ao catolicismo (Gibson, 1964: 58-97). A referência mais antiga à atual Cuetzalan é o povoado de Quetzalcoatl, que se encontrava próximo à sede atual (García Martínez, 1987: 114). Em 1533, o povoado fazia parte da encomienda de Pedro Cindo Portillo (ibid.: 162-163). Esse regime, que permitiu todo tipo de abuso, não durou muito tempo na Serra: não encontrando nenhuma mina, os “encomenderos", ávidos por riqueza, foram a outra parte. No final do século XVI, a maioria das comunidades indígenas era administrada por corregedores ou prefeitos que dependiam diretamente do vice-rei da Nova Espanha (ibid.: 311-319).

Oshabitantes foram dizimados porepidemiasquesesomaramaos transtornosdaConquista. Consequentemente, em 1554, o tributo que pagava a população de Quetzalcoatl foi reduzido de quatro cargas e meia de mantas de algodão parauma(García Payón, 1965: 63, nota43). Em seguida, a comunidadejánãoémencionada. Foi quandoas autoridades religiosas decidiram agrupar os vizinhos “fora dos cânions e montanhas onde viviam antes” (García Martínez, 1987: 162-163), de acordo com a política de congregações aplicada pelo clero e pela Coroa espanhola. Em 1550, quando Queçala (Cuetzalan) obteve sua primeira concessão de terras, a população total era de 240 habitantes (García Martínez, 1987: 324, 358).

A partir de então, observa-se uma estabilização e, em seguida, um ligeiro aumento da população entre os indígenas. No início do século XVII, Cuetzalan teve uma paróquia com sacerdote residente e sua população cultivava 
milho, pimenta e algodão. Também se dedicava à caça e à pesca e criava galinhas e perus (De la Mota e Escobar, 1940: 225). Em 1646, o bispo de Puebla, durante uma visita, avalia sua população em duzentas famílias (cerca de mil habitantes) e diz que "sua igreja é uma das melhores” na região (Palafox e Mendoza, 1643-1646, f76r).

Em 1720, Cuetzalan aparece nos arquivos da sede de San Juan de los Llanos (atual Libres) como “República de índios", ou seja, comunidade autônoma com seu próprio governador. Este fez parte de uma delegação de governadores indígenas do sul da Serra que foram a San Juan de los Llanos para apresentar uma queixa ao vice-rei da Nova Espanha, que estava de visita, contra um trabalho de reparação de estradas que quiseram impor em Xalapa, ou seja, a "vinte léguas de sua casa" (cerca de 110 km). O vice-rei, o Marquês de Valero, deu-lhes razão apesar dos protestos das autoridades civis de Xalapa (Arquivo Histórico do Município de Libres, 30/10/1720). Quando se examinam os argumentos dos índios, chama atenção sua familiaridade com as leis coloniais vigentes e, até mesmo, sua habilidosa utilização do pouco conhecimento do território que tem o vice-rei. Por exemplo, eles argumentavam que teriam que abandonar suas lavouras "com as quais pagam os tributos", enquanto que, em outubro, a principal colheita do milho já estaria feita. Eles afirmaram que o clima de Xalapa era muito prejudicial para eles, sendo que era o mesmo das serras baixas de Puebla ... (ibid., 1720/10/30). Do protesto que fizeram - tarde demais - as autoridades de Xalapa concluíram que alguns nativos do sul da Serra chegavam a Xalapa "para vender os seus produtos" (ibid.).

Cinco anos depois, em 1725, a população de San Francisco Quesala [Cuetzalan] passou da luta jurídica para a ação direta. Rebelou-se contra o padre, contra o tenente e contra Juan Antonio, "índio fiscal deste povoado", e os expulsou do povoado. O motivo: as humilhações e multas exorbitantes que o tenente praticava em suas visitas bastante frequentes a Cuetzalan, as contribuições na forma de trabalho e em dinheiro que o padre exigia sem parar, e os "abusos" do fiscal. Após um inquérito, os índios ganharam a causa, mas os rebeldes, que haviam sido presos, foram espancados por terem se insurgido contra a autoridade! (Arquivo Geral da Nação, Índios, 50: ff344-347). Graças a esse documento, sabe-se que já havia vários povoados na freguesia (idem 50: f344r); também que havia um residente não-indígena (o padre) e que este cultivava milho e cana-de-açúcar com a mão de obra indígena gratuita.

Desde o final do século XVIII, as relações entre os povos indígenas e a administração foram intensificadas como resultado das reformas modernizadoras dos Bourbons. Esse maior controle burocrático pode ter sido acompanhado por um aumento da carga fiscal. Em 1779, Antonio Francisco, "Governador de Bens Naturais de Quezalan” também foi encarregado dos assuntos religiosos. Ele declara como entrada “90 pesos de esmolas que deram os filhos [ou seja, os fregueses] para as funções da igreja, já que não tinham bens coletivos e não podiam cultivar, posto que a terra era íngreme" (Arquivo Histórico do Município de Libres, 1779, s.n.f. 1r). Reporta gastos, para o mesmo ano, de "108 pesos para o padre celebrar as missas de domingo e de festas e 36 para as velas" (ibid.). Termina, portanto, reconhecendo que deve 18 pesos, acrescentando que essa dívida "é [também] de seus regedores e prefeitos" (ibid. fl v). O governador também se ocupava com funções civis. Em 1788, Juan García, sucessor de Antonio Francisco, escreveu que recolheu 138 pesos e um real de tributo "na razão de um real e meio por tributário". Os tributários eram 740, o que leva a supor a existência de cerca de 3.700 habitantes (Arquivo Histórico do Município de Libres, 26/03/1788). Os únicos custos admitidos foram os 79 pesos de salário para o professor que a república de índios devia contratar, uma contribuição 
especial de dois por cento e quatro reais de gastos. O resto, ele teve que entregar para o caixa da comunidade mantido na sede do distrito de San Juan de los Llanos. Nota-se que, em 1792, a Serra Norte de Puebla como um todo tinha 138.773 habitantes, ou seja, 27\% da intendência de Puebla (506.654 habitantes); destes, 17\% foram classificados como “espanhóis" e 83\% como "índios” (Thomson, 1999: 25).

O que nos revelam esses documentos? Em primeiro lugar, que a economia de Cuetzalan colonial não era apenas de subsistência, mas também havia suficientes trocas monetárias para, pelo menos, gerar os 228 pesos anuais de esmolas e impostos. Para se ter uma ideia do poder de compra dessa quantidade, deve-se mencionar que o salário local, era, na época, de cerca de dois reais por dia (Arquivo Histórico do Município de Libres, 10/08/1823). Isso nos dá um tributo total equivalente a 912 dias de trabalho, ou seja, 1,2 dias por tributário. A isso teriam que ser adicionadas as tarefas, civis e eclesiásticas, das quais não há dados precisos, ainda que sua existência esteja comprovada por documentos (Arquivo Histórico do Município de Libres, 30/10/1720).

Na esfera administrativa, a comunidade alcançou, no século XVII, um estatuto de relativa autonomia, uma vez que tinha relações mais intensas com a administração colonial. Essas relações eram mediadas pelas autoridades indígenas, o governador, os regedores e prefeitos. Eles tentavam, e às vezes conseguiam, defender os interesses da população, como no caso do trabalho de Xalapa. Pode-se interpretar assim, também, a estranha declaração do governador Antonio Francisco de que "não podem plantar por serem as terras muito íngremes". Ao contrário, sabemos que eles tinham um título desde meados do século XVII e que a terra, mesmo íngreme, era muito fértil (ver Arquivo Histórico do Município de Libres 18/06/1787, f5v). É mais provável que os indígenas de Cuetzalan preferiram pagar em dinheiro e não em espécie como ocorria em muitas comunidades das terras altas. A venda de produtos agrícolas e de aves de curral ("suas criações") lhes proporcionava dinheiro mais facilmente e assim evitavam carregar o produto para San Juan de los Llanos!

É possível ver também o crescimento demográfico: a "república de índios" passou de 1.000 a quase 4.000 habitantes entre 1650 e 1790. O aumento da população era natural em sua maior parte, mas também a tradição oral reporta a imigração durante o período colonial, de um grupo de indígenas das terras altas que fundaram a cidade de San Miguel Tzinacapan, na parte ocidental, então desabitada, da "república de índios de San Francisco Quezala" (Taller de Tradición Oral, 1994). Essa população crescente significou uma mudança na relação com o meio ambiente. Em primeiro lugar, o aumento da área cultivada reduziu a floresta que outrora se estendia por quase todo o território do município atual. Em geral, a expansão foi feita a partir do centro-sul, ao pé das montanhas, onde estão os três principais assentamentos: San Francisco Cuetzalan, a sede, San Miguel Tzinacapan (oeste) e San Andrés Tzicuilan (leste), em direção às encostas menos íngremes, mais quentes e férteis do norte. Na parte baixa do município, já havia uma aldeia indígena no final do período colonial, Santiago Yancuictlalpan.

Os anciãos de San Miguel Tzinacapan contam que estabeleceram seu povoado na parte mais elevada do sul (750 metros), ao pé das colinas, para aproveitar uma fonte de água permanente, porque nas encostas mais baixas as fontes não jorram em tempos de seca (abril e maio) (Taller de Tradición Oral, 1994: 84-86, 97-99). Mas a terra ali é 
íngreme e rochosa, razão pela qual tantos habitantes de San Miguel como cuetzaltecos e tzicuilenhos sempre preferiram cultivar na área mais temperada (entre 500 e 700 metros), onde, além disso, podem obter duas safras de milho por ano. A exploração de diferentes níveis ecológicos também permitia uma rotação de solos. Um documento relata:

"Antes da lei de desarmotização, a classe indígena, que era a mais numerosa, ocupava uma pequena parte, plantando durante um ano num reduzido terreno, sem renda suficiente para sua subsistência anual e, realizada sua colheita, separava-se para outro lugar onde fazia outra pequena clareira, abandonando a que antes havia ocupado, para sua nova plantação". (Arquivo Histórico do Município de Cuetzalan, 12/09/1877)

A agricultura local era bastante diversificada. A lista mais antiga de cultivos que encontramos, escrita em 1904, indica 58 cultivos locais, 36 deles autóctones, incluindo grãos, verduras, frutas e quelites (Jáimez, Ramírez e Valderrama, 1992: 29-30). Além da área cultivada, a área de floresta ainda abundante proporcionava madeira e lenha à população, folhas de abacateiro (Beilschmedia anay [SF Blake] Kostermans) para cobrir as casas, animais e aves silvestres para a caça, enquanto dos rios eram tirados os peixes e crustáceos.

Essa exploração generalizada dos recursos foi possível graças à posse comunal (común de naturales) que prevaleceu durante todo o período colonial. As autoridades espanholas tinham reconhecido a posse coletiva da terra entre os grupos indígenas e esses títulos coletivos foram a base jurídica da república de índios. As autoridades locais eleitas administravam esses bens de maneira relativamente autônoma, enquanto cumpriam com o exercício das obrigações fiscais e religiosas. Mas este território passou a despertar a cobiça de estranhos, especialmente depois que as reformas de Bourbon, na segunda metade do século XVIII, permitiram a qualquer um cultivar as terras "inutilizadas" das comunidades com o suposto objetivo de aumentar a produção agrícola.

Em 1808, tem início um longo processo que opôs os “nativos da República de Índios de SanFrancisco Quezala" a Don Alonso García Luque, vizinho de San Juan de los Llanos (atual Libres), sobre as terras de Xocoyolotepec, a parte mais alta e meridional do común de naturales, onde os indígenas não costumavam viver nem cultivar (Arquivo Geral da Nação, Terras, 1808). Essas terras “baldias” foram primeiramente exploradas e avaliadas (Arquivo Histórico do Município de Libres, 25/11/1791) de acordo com a nova política a que aludimos. Em seguida, de acordo com a denúncia, colonos de "razão" fizeram ali uma "grande fazenda". Ao mesmo tempo, os cuetzaltecos decidiram plantar no local quatro fanegas (24 hectares) de milho, a fim de vender grãos para a despesa de reconstrução da igreja paroquial que tinha sido queimada (Arquivo Geral da Nação, terras, 1808: 7). García Luque entrou na milpa, com homens armados, pegou à força os indígenas que cuidavam da plantação e colocou fogo. As autoridades cuetzaltecas mantiveram a calma entre os “quatrocentos índios presentes” e apresentaram uma demanda em San Juan de los Llanos. Em vão: ali as autoridades mandaram deter e encarcerar o governador de Cuetzalan, tomando o seu cajado, símbolo de seu cargo (ibid.). Os membros da comunidade denunciaram o conluio entre o agressor e as autoridades de San Juan e conseguiram que o assunto fosse transferido para um juiz imparcial. O caso terminou com uma decisão favorável aos indígenas. 
Assim como o resultado do pleito, é a estratégia implantada pelos cuetzaltecos para defender seu território o que nos interessa aqui. Em seu argumento jurídico, insistem no caráter recente da chegada de forasteiros em Xocoyolotepec (“de pouco dias até o presente"), que se opõe à sua "posse tranquila durante muitos anos" (ibid.: 14). No entanto, sabemos que os primeiros colonos mestiços se estabeleceram em Xocoyolotepec em 1791, ou seja, 17 anos antes do início do conflito com García Luque. Em 1792, foi registrado em Cuetzalan o batismo do primeiro menino não-indígena (Arquivo da Paróquia de San Francisco, Livro de batismos, 1792). Contrariamente ao novo invasor, esses colonos eram visivelmente camponeses, que ocupavam pequenos lotes e não há registros de conflitos com seus vizinhos indígenas . Frente à invasão massiva de García Luque e sua gente, os cuetzaltecos decidiram que a ocupação física da terra era a melhor maneira de apoiar a sua reivindicação. Em sua demanda, conferem uma dimensão religiosa a seu gesto: o fruto da milpa era para reconstruir a igreja queimada. Se levarmos em conta a preferência que os mesmos tinham expressado vinte anos antes pelo dízimo individual pago em dinheiro, parece razoável acreditar que buscaram matar dois coelhos com uma cajadada só: arrecadar dinheiro para a igreja, certamente, mas também fazer valer os seus direitos coletivos a essas terras, os quais não haviam sido alcançados com as pequenas plantações. García Luque entendeu isso bem, destruindo a milpa, em vez de tentar apropriar-se da colheita. Embora o objetivo dos cuetzaltecos (a colheita) tenha sido frustrado, o segundo e mais importante, legitimar seu título agrário, foi plenamente alcançado.

No final do período colonial, os dados de arquivos consultados revelam uma comunidade numerosa, Cuetzalan, que afirma seu controle sobre todo o seu território, além das terras agrícolas. Ela faz isso dentro dos limites do marco colonial, com base na congregação que foi criada em meados do século XVII. Os cuetzaltecos utilizaram os espaços oferecidos pelo marco jurídico e político da época para escapar da tutela das grandes cidades indígenas, Tlatlauquitepec, primeiro, Zacapoaxtla, depois, e tornar-se uma república de índios como eles. A partir de então, eles passaram a enfrentar periodicamente a capital do distrito, San Juan de los Llanos.

Ao mesmo tempo em que lutava externamente para levar a cabo o processo de cisão com suas antigas sedes, Cuetzalan continuava, internamente, seu próprio processo de segmentação, com a expansão da população em busca de terras cultiváveis. Essa identidade local segmentada é revelada primeiramente em âmbito religioso: entendemos que "três comunidades próximas" (provavelmente Cuetzalan, Tzicuilan e Tzinacapan) tinham suas próprias igrejas em 1725 (Arquivo Geral da Nação, Índios 50: 344). Em 1791, Santiago Yancuictlalpan foi reconhecido como pueblo sujeto distinto (García Martínez 1987: 378). Entretanto, frente à interferência constante, tanto civil como eclesiástica, em seus assuntos internos, a resposta foi a unidade. O conjunto do povo optou, segundo as circunstâncias, ou pela negociação (impostos e dízimos no século XVI, trabalho de Xalapa, em 1720); ou pela rebelião aberta (o motim de 1725); ou por uma combinação de ação direta e disputa judicial (conflito de Xocoyolotepec). O motivo comum dessas diversas lutas parece ser a defesa do controle sobre o território comunal, dentro do qual as famílias indígenas pudessem cultivar, caçar, pescar, coletar produtos silvestres, cortar madeira, segundo suas necessidades, aproveitando a fertilidade do meio e as condições de baixa pressão demográfica. Chamamos essa consolidação ambiental e sociopolítica de segundo ordenamento territorial de Cuetzalan, fruto das práticas e dos valores indígenas, e que se manteve durante todo o período colonial. 


\section{A REPÚBLICA E A INTERVENÇÃO FRANCESA}

Não existe testemunho, oral ou escrito, de que os indígenas da serra baixa tenham participado das guerras de independência, em um ou outro grupo. Nas comunidades, como na maioria dos povoados indígenas do centro e sul do México, depois da independência continuou o paulatino aumento demográfico, apesar das epidemias que fizeram estragos até em pleno século XX. Esse aumento foi particularmente notável em zonas como as de ZacapoaxtlaCuetzalan, que estavam pouco povoadas antes da Conquista. $\mathrm{O}$ documento fiscal citado anteriormente fala de 740 tributários para Cuetzalan, o que representa uma população total estimada em cerca de 3.000 pessoas em 1788 . Um século depois, em 1871, a população havia mais que duplicado, chegando a 7.799 (Thomson, 1991: 218). Entre 1792 e 1869, a população total da Serra cresceu a um ritmo de $0,4 \%$ ao ano, ou seja, o dobro do crescimento do Estado de Puebla (Thomson e La France,1999: 25).

O meio século que se seguiu à independência do México foi marcado pela instabilidade política, que alcançou a Serra Norte de Puebla. Documentos dispersos relatam a chegada de tropas “insurgentes" ou "rebeldes", cuja presença era um peso e uma ameaça para as comunidades (Arquivo Histórico do Município de Cuetzalan, 07/11/1872). No âmbito político, o processo de segmentação que permitiu o nascimento de Cuetzalan havia deixado sequelas, na forma de conflitos não resolutos. O documento mais antigo conservado em Cuetzalan, com data de 1822, refere-se a uma demanda de compensação pelas contribuições que se fez a Zacapoaxtla "quando estes povoados estavam submetidos àquela sede, para reconstruir as casas consistoriais" (Arquivo Histórico do Município de Cuetzalan,1822, s.f.). Ao longo do século XIX, manifestou-se o problema dos limites municipais. Cuetzalan cresceu entre duas sedes de origem préhispânicas, Tlatlauquitepec e Jonotla, e teve que definir e defender seus limites contra esses vizinhos que reivindicavam “direitos reconhecidos desde os tempos imemoriais" (Arquivo Histórico do Município de Cuetzalan, 01/07/1861). As partes recorreram à ameaça e à intimidação (Arquivo do Município Auxiliar de Tzinacapan, 26/02/1861), ao pagamento de compensações (a Jonotla) e, inclusive, a uma comissão de arbitragem que percorreu as montanhas e vales para marcar o limite sudoeste com Tlatlauquitepec, até que chegaram às fronteiras reconhecidas por todas as partes.

Em âmbito interno, Tzinacapan reclama porque "gente da sede vem cultivar nossas terras" (Arquivo do Município Auxiliar de Tzinacapan, 13/07/1862); Tzicuilan chega a um acordo sobre sua fronteira com a sede (Arquivo Histórico do Município de Cuetzalan, 22/04/1869); enquanto que Xocoyolo reclama a mesma parte de seu território “que a havia emprestado" 56 anos antes! (ibid. 20/01/1873). Notamos uma dimensão estrutural da oposição entre os povoados e as sedes, anterior inclusive aos conflitos interétnicos, que a aparecem no fim do século XIX, ainda que depois os dois tipos de conflitos coincidam.

\section{A SUPRESSÃO DO “COMÚN DE NATURALES” E SUAS CONSEQUÊNCIAS}

Uma das reformas mais importantes impostas pelos liberais, em 1856, foi a supressão dos títulos chamados “de mão morta”, que caracterizavam tanto as propriedades eclesiásticas como as terras comunitárias indígenas. O 
presidente Juaréz, de origem zapoteco, considerou que esse tipo de propriedade era uma das causas do atraso social e cultural dos povos indígenas do México e sonhou em transformá-los em prósperos agricultores sobre terras privadas, como no vizinho país do Norte.

A Lei Lerdo obrigou a por em venda livre essas terras. Ainda que, a princípio, os usuários deveriam ter prioridade como donos privados, saiu favorecido um número muito reduzido de especuladores, amigos do novo regime. Entretanto, em uma zona montanhosa como a Serra, poucas terras suscitaram a cobiça de grandes empresários agrícolas como na planície central ou na costa de Veracruz.

AIntervençãoFrancesa(1862-1867) criou um novo contexto sociale político no país ena Serra. Oscuetzaltecos, como os demais habitantes da região, estiveram, a princípio, divididos entre dois grupos: de um lado, o clero local apoiava firmemente os conservadores e a Intervenção; de outro, vários líderes indígenas, entre eles Juan Francisco Lucas, de Xochiapulco, e Francisco Agustín Dieguillo (Palagosti), de Cuetzalan, ergueram-se contra os invasores franceses. (Taller de Tradición Oral 1994: 101-124). Por trás da lenda dos “zacapoaxtlas” está a presença efetiva em Puebla, em 5 de maio de 1862, do Sexto Batalhão, formado por 150 homens de Xochiapulco e Cuetzalan, sob as ordens de Juan Francisco Lucas e de Franciso Agustín Dieguillo. Em 2 de abril 1867, na batalha decisiva em Puebla, Dieguillo estava à frente de uma companhia completa de cuetzaltecos, sob o mando de Lucas (Thomson e La France, 1999: 77, 133). Uma batalha importante ocorreu em Cuetzalan em novembro de 1864: o ataque liberal, dirigido pelo general Maldonado coincidiu com uma tormenta com raios que alcançaram o campanário da igreja, o que foi interpretado pela população como um castigo sobrenatural às forças estrangeiras (Maldonado, cit. por Thomson, 1999: 9). Após a derrota do exército imperial, decidiu-se aplicar a Lei Lerdo de desamortização na Serra Norte (dezembro de 1867).

Essa nova situação jurídica impulsionou vários mestiços, recém-chegados à sede e que se dedicavam principalmente ao comércio, a apossar-se de terras onde iniciaram o cultivo de cana e café e a criação de gado. $\mathrm{O}$ fato provocou uma rebelião dos membros da comunidade em Cuetzalan. Sob a direção de Palagosti, opuseram-se à privatização das terras comunais pela burguesia local e destruíram os currais e as plantações (Thomson, 1991: 221222). Com a mediação de Lucas, os camponeses indígenas puderam registrar como parcelas privadas a maior parte de suas terras de trabalho (Thomson e La France, 1999: 133-134). Encontramos múltiplas denúncias de parcelas nos anos 1868 e 1869 (Arquivo Histórico do Município de Cuetzalan). Anos depois, frente às tentativas das autoridades municipais de cobrar créditos pelas terras adjudicadas, a Chefia Política de Zacapoaxtla contestou o prefeito de Cuetzalan: “Os proprietários ou arrendatários das terras do común de naturales desde os tempos imemoriais não estão obrigados a nenhum recenseamento nem ônus [...] pois deve dar- lhes absoluta propriedade por presumir de antemão que as possuíam com esse caráter.” (idid. 20/03/1877).

O fato de que todas essas parcelas estiveram designadas por topônimos indígenas confirmou a antiguidade e a apropriação material e simbólica do território pelos Nahua. De fato, os poucos topônimos em castelhano concentraramse na zona sudeste do município (bacia do Cuichat), onde a burguesia da sede estabeleceu suas fazendas cafeeiras nas terras comunais que não foram adjudicadas a indígenas. 
Um dos empenhos do novo município foi a melhoria das comunicações com o centro do país, condição indispensável para a rentabilidade de suas atividades comerciais e produtivas. Empreendeu-se um amplo programa de obras públicas para transformar parte da rede de caminhos reais, aptos apenas para mulas e pedestres, em uma estrada. O meio utilizado foi a intensificação e a reorientação das tarefas comunitárias. Enquanto anteriormente serviam, sobretudo, à manutenção dos edifícios religiosos (agora esses eram voluntários) e cívicos, passaram a ser destinadas “à estrada", com fortes multas ou pena de prisão aos que não se conformavam (Arquivo do Município Auxiliar de Tzinacapan, 06/09/1873).

Tanto o parcelamento das terras, como a instalação de forasteiros e as transformações econômicas e de comunicações tiveram consequências muito importantes para o ordenamento territorial e o ecossistema. No âmbito social e cultural, Cuetzalan se transformou em uma sociedade pluriétnica. No mesmo processo, depois que Francisco Agustín Dieguillo encerrou seumandado de prefeito, os indígenas se encontraram excluídos dopoderpolíticomunicipal, o que se traduziu por sua expulsão física da sede. Sob múltiplas pressões, sobretudo econômicas (como o embargo de propriedades por dívidas), os indígenas se deslocaram para os antigos pueblos sujetos agora chamados municípios auxiliares, Tzinacapan, Tzicuilan, Yancuictlalpan, Zacatipan, onde podiam manter certo nível de autonomia, dentro dos limites impostos pelas mudanças legislativas.

\section{O CONTROLE SOBRE A POPULAÇÃO: A REFORMA ADMINISTRATIVA}

Durante o longo mandato de Porfírio Díaz (1876-1910), uma prioridade foi a restauração da ordem social e a reforma administrativa. Os governadores e os conselhos de anciãos das "repúblicas de índios" foram definitivamente substituídos pelo prefeitos municipais, os regedores e os juízes. Quiseram obrigar os povoados indígenas a funcionar segundo um modelo administrativo uniforme, no qual determinavam até os menores detalhes. No entanto, nesse local os títulos parecem ter sido mais uma formalidade do que voltados para o desempenho das suas funções. Com uma exceção notável: o secretário, que deveria expressar-se bem por escrito em castelhano. Durante uma longa temporada, recorreu-se geralmente a um mestiço da sede capaz de redigir os múltiplos relatórios exigidos pelas autoridades do distrito. Estas autoridades e, em particular, o chefepolítico nomeado pelo próprio Porfírio Díaz, relatavam imediatamente qualquer desvio da norma: quer tratasse da definição das respectivas responsabilidades dos dirigentes locais (Arquivo Histórico do Município de Cuetzalan, 06/10/1872), do número de alunos matriculados, de sua frequência à escola e, até mesmo, da atribuição de notas (Arquivo do Município Auxiliar de Tzinacapan, 23/06/1873).

\section{O CONTROLE SOBRE A POPULAÇÃO: CENSO E FISCALIZAÇÃO}

Ordenar quer dizer conhecer, daí a importância do “padrão de moradores”. A partir de 1860, encontramos um padrão de moradores anual, além de listas de produtores de cana-de-açúcar, de vendedores de carne na praça etc. Desse momento em diante, foram priorizados o controle fiscal e a lista de contribuições a pagar: "pessoal", "para a escola", "de Chicontepec"... O Estado liberal considerava que o campo deveria suportar o custo da modernização e buscava sempre mais dinheiro. Por exemplo, vendo que os indígenas resistiam a enviar os filhos ao serviço militar, foi criado um novo imposto chamado "de rebaixados” com o qual se poderia resgatar um recruta (Arquivo Histórico do Município 
de Cuetzalan, 29/11/1872). Com a supressão das terras comunais, os camponeses indígenas tiveram que registrar suas parcelas individualmente. As autoridades municipais tentaram fazer com que todos pagassem anualmente os $6 \%$ do valor estimado da terra "adjudicada", não apenas os novos donos mestiços cujas terras valiam mais de 200 pesos (Arquivo Histórico do Município de Cuetzalan, 16/03/1877), mas os indígenas também. No entanto, vimos que essa proposta não prosperou. Para todas essas contribuições foram nomeados cobradores que não podiam renunciar e que eram responsáveis pela integridade das quantias a cobrar, sob pena de terem seus bens confiscados.

\section{A NOVA ORDEM REPUBLICANA: A REVOLUÇÃO SIMBÓLICA}

Se nos chamam a atenção as continuidades demográficas e sociais, as rupturas também são evidentes. Após a vitória eleitoral de 1856 e a vitória militar sobre as forças de intervenção em 1867, a nova ordem liberal quis distinguirse ao máximo da ordem anterior. A separação da Igreja e do Estado teve, a princípio, pouca ressonância nos povoados, salvo quando padres e autoridades municipais se desentendiam sobre a propriedade de terrenos e edifícios (Arquivo Histórico do Município de Cuetzalan, 16/06/1873). Nos documentos oficiais, suprimiram os nomes de santos que os religiosos espanhóis tinham copiado dos topônimos indígenas, ainda que a população siga usando até hoje. Após a supressão dos dízimos e de outros direitos eclesiásticos, ordenou-se aos "mayordomos de confrarias" que entregassem ao Estado seus “capitais” (Arquivo do Município Auxiliar de Tzinacapan, 09/03/1861). No entanto, não podemos averiguar se tais medidas foram aplicadas.

Para contestar a influência do clero católico, que os liberais associavam ao grupo conservador, propuseram novos símbolos: a pátria, o progresso e a educação. $\mathrm{Na}$ sede, os edifícios públicos modernos foram o símbolo da nova ordem e do grupo étnico mestiço, agora dominante (autonomeado "de razão"). Com o trabalho indígena foram construídas as novas casas consistoriais: "[...] para substituir o antigo palácio, palagosti, que tinha teto de palha" (Estela Flores, 1969). O frontão, certamente, chegou a ter a estátua de um índio, mas de um glorioso índio do passado, Cuauhtemoc, apropriado pelos mestiços e não de um indígena atual. Com o trabalho reconstruíram a igreja paroquial de São Francisco e construíram as escolas. O relógio público, que marca o tempo moderno, competiu com o campanário, que ainda marcava o tempo antigo, o de missas e ângelus. Também promoveram as festas pátrias e cívicas, brilhantes e onerosas: aos comerciantes da sede eram pedidas contribuições em dinheiro e aos camponeses dos povoados, trabalho e materiais: "Para Tzinacapan, quarenta homens e lhes avisem que devem se apresentar com a madeira e os cipós, Yancuictlalpan, trinta [...] amanhã, sem falta” (Arquivo do Município Auxiliar de Tzinacapan, 01/10/1873). Nos povoados, levaram a cabo obras similares, mas com menos esplendor.

\section{ACOMODAÇÃO, NEGOCIAÇÃO, REBELIÃO: A RESPOSTA INDÍGENA}

Como reagiram os camponeses indígenas a essas mudanças? De múltiplas maneiras, segundo as circunstâncias. Vimos como Francisco Agustín Dieguillo, o Palagosti, como era chamado localmente, depois de participar da luta armada durante a intervenção franco-austríaca junto ao caudilho liberal Juan Francisco Lucas, resistiu à privatização das terras comunais e, em janeiro de 1868, aceitou as recomendações da comissão de reconciliação presidida pelo 
próprio Lucas, que propôs aos camponeses registrar suas parcelas. O parcelamento abarcou, pouco a pouco, todo o común de naturales, apesar dos vários motins locais nos anos subsequentes (Thomson, 1991: 239). Nas gerações seguintes, enquanto a população indígena da sede era desalojada pelos mestiços, o crescimento demográfico e o jogo das heranças também impulsionavam os agricultores a construir suas casas nas parcelas que herdavam mais abaixo. Assim se formaram os povoados e casarios que se encontram hoje em todo o município (Taller de Tradición Oral, 1994).

Uma definição estreita da resistência territorial indígena em Cuetzalan chegaria à conclusão de que esta se limitou a uma sublevação, dirigida por um líder valente, uma batalha, perdida de antemão, contra o curso inexorável da história. Essa é a visão que se depreende do estudo de Thomsom, que trabalhou essencialmente a partir dos informes que os adversários políticos de Palagosti, a burguesia mestiça de Cuetzalan, mandavam à sede do distrito. Segundo os arquivos que investigamos do povoado indígena de São Miguel Tzinacapan, a visão é distinta. (Ver Ramírez, Jáimeze Valderrama, 1992).

De fato, a rebelião de 1868 aparece como um aspecto da resistência indígena e do próprio papel que teve Dieguillo.Porexemplo, em 1854, ocenso mais antigo que encontramos(ArquivodoMunicípioAuxiliarde Tzinacapan, 1854, s.f.) faz referência apenas aos homens. Parece que foi realizado com fins militares, se jugarmos pelas informações pedidas: "idade", "pátria" e "estado civill. Particularmente interessante é o campo "exceções": a única menção que aparece, sempre junto aos nomes de homens entre 18 e 40 anos, é “índio puro". A ausência de outras informações leva à formulação da hipótese de que foi recebida uma ordem de inscrever todos os homens válidos, para, eventualmente, recrutá-los ao exército. Aproveitando uma cláusula de exceção aplicável aos “índios puros”, que os considerava inaptos ao serviço militar por motivos linguísticos e culturais, os autores do censo atribuíram essa qualidade a todos que eram suscetíveis de serem recrutados. Sabendo que os homens levados ao exército muito provavelmente não voltavam, as autoridades locais tinham encontrado esse estratagema para eximi-los. Depois, como dissemos anteriormente, os indígenas preferiram pagar o imposto chamado "de rebaixados" com a mesma finalidade.

Se voltarmos a Francisco Agustín Dieguillo, observamos que ele teve outros papeis além de um caudilho militar surgido do motim. Em 1862, pouco tempo antes da rebelião contra os franceses, foi eleito regedor: o que sugere que falava bem espanhol, era alfabetizado e gozava de certa estima, pelo menos entre a população indígena, então maioria na sede. Após a revolta, foi novamente regedor, administrador e até prefeito. Se o Palagosti guerrilheiro foi um defensor das terras comunais, o Palagosti prefeito contribuiu fortemente para a consolidação da ordem liberal. Sob a nova legalidade, como administrador, paralisou algumas tentativas de privatização de terras (Arquivo Histórico do Município de Cuetzalan, 10/01/1873) e até criou um ejido (localizado perto do rio Cuichat, esse ejido seria privatizado depois, quando o poder municipal passou para as mãos da burguesia mestiça). Ao mesmo tempo, Palagosti relançou a construção dos edifícios públicos, do palácio municipal, da escola e até mesmo de uma prisão "para prender os bêbados" (id. 17/02/1873) e insistiu para que os pueblos sujetos participassem do esforço (id. 20/10/1872). Promoveu a construção de pontes e a recuperação de estradas (id.06/11/1872) e repreendeu seus assistentes nas aldeias que tardaram 
em cobrar impostos e organizar as tarefas.

Esse primeiro prefeito indígena não quis se opor aos mestiços e apoiou o seu comércio. Concedeu-lhes terras, mas na periferia, reservando os terrenos mais próximos para a agricultura camponesa. Pode-se dizer que Palagosti sintetizou em sua pessoa as distintas respostas indígenas frente à penetração da ordem liberal: primeiramente, a oposição armada quando ainda parecia possível impedir a privatização do común de naturales, seguida da negociação e o uso do novo marco administrativo e legal para deixar a cidade em uma melhor posição no México que estava nascendo. Infelizmente, para os indígenas, com a tomada do poder municipal pelos mestiços, essas ferramentas acabaram ficando fora do seu controle. Além disso, a própria autoridade mestiça local seria subordinada, até os anos 1970, ao poder dos caciques regionais, os proprietários da fazenda Apulco, que controlavam a produção e o comércio de aguardente na região (Paré, 1975). Porém, a expansão do cultivo do café no século XX, deslocou gradualmente os canaviais e alterou profundamente a estrutura social e o ecossistema, estabilizando um novo modelo de relação com o território, que nasceu a partir da privatização da terra e que examinaremos agora.

\section{CLASSIFICAR E NOMEAR O TERRITÓRIO: ETNOTOPOGRAFIA E TOPONÍMIA}

As práticas ambientais nahua supõem um conhecimento detalhado das microrregiões onde se encontram as centenas de plantas que eles cultivam e coletam, os animais que criam e caçam, os peixes e mariscos que capturam (Taller de Tradición Oral e Beaucage, 1997b).

A categoria mais geral que existe em nahua para designar o lugar é taltikpak (taltik, "barrento"; -pa[n], sufixo locativo "sobre, em meio a"; -k[o], sufixo locativo "sobre"). Refere-se à "superfície material da terra", distinto de talmanis (tal, "terra", -manis, sufixo de qualidade "plano") que designa a sua "superfície abstrata" e de semanauak (se, "um"; mana, "estender-se"; -nauak, sufixo locativo "próximo") que corresponde ao "universo". Encontramos 41termos para designar os tipos de lugares, com a quais se formaram, apenas no território de San Miguel Tzionacapan, 310 topônimos.

Eles podem ser agrupados da seguinte forma:

Em primeiro lugar, em relação à montanha ou morro (tepet), característica mais marcante da paisagem de serrana. Suas partes são designadas por uma metáfora antropomórfica: a parte superior ou "cabeça" (tepekuako, "a cabeça do morro") com sua borda ou "boca" (tepeten), os penhascos verticais ou "pernas" (tepexit), suas encostas ou "coxas" (tepekespan) e seu pé ou "ânus" (tepetsintan) . O "coração da montanha" (Tepeyolo) não se refere simplesmente ao seu interior, mas a uma entidade espiritual temível que a protege e fica irritada quando a dinamitam para fazer estradas. A base está frequentemente cheia de deslizamentos (taxitin) e de rochas espalhadas (teyeual). As rochas sedimentares afloram constantemente, tomando, às vezes, a forma de uma "escada" (teejkauas) ou "semeadas ao vento" (temimil). As aldeias são estabelecidas frequentemente na metade da encosta, nos poucos espaços relativamente planos (tamayan), próximos de fontes de água (apan) permanentes. Além das margens (tatempan, “boca de coisas”), 
abaixo (tatampa, "sob as coisas" ou taltsintan, "no ânus da terra") aparecem as colinas ou “cabeças de terra” (talkuait), com suas encostas ou "coxas" (takes), que podem estender-se em um pequeno campo (tamanis) ou estarem separadas por depressões (tauakal), buracos (akuakualachtaj), barrancos (tatekoch) e abismos (ostok). Os locais particularmente acidentados, rochosos e cobertos de mato são designados de forma geral pelo termo ouijkan ("lugares dificeis"). Os topônimos que se referem explicitamente às montanhas ou colinas são 36.

Em segundo lugar, estão as águas terrestres (at, "água", atauit "riacho").

Rio acima (apankuako, "riacho-sua-cabeça"), o fluxo provém de uma fonte (apan, atmemeya) e desliza entre as suas margens (seus "lábios", sua “boca”, atenoj, ataujtenoj). Rio abaixo (atsintan, "água-seu-ânus”), cresce a cada confluente (atsalan, "entre águas", atmonamiki, "água-se-encontra") e converte-se em rio (ueyat, "água grande"). Ali suas margens íngremes tomam a aparência de falésias (tepamit, "paredão"). Onde a água é escura (tiltikat), encontramse os poços (axoxouil, "água verde") ricos em peixes e crustáceos. Às vezes, o rio se divide (amaxal), desaparece (atpoliui) em um abismo, brota (atmolon) ou salta em uma cachoeira (atpauetsi, atpanchachalaka), cavando uma caldeira (akonko "panela de água", ajpasapan "vasilha de água"); às vezes, expande-se em uma lagoa (amayan) ou lago (amanis). Em lugares calmos, encontra-se o vau (panaloyan). Nas terras baixas do norte, a água se perde, por vezes, em um pântano (chiauit), enquanto as fontes de água potável se tornam escassas. As águas terrestres, em suas várias formas, são mencionadas em 94 topônimos.

Uma terceira categoria faz referência às características edafológicas do solo, que geram 54 topônimos. Na área montanhosa do sul, os lugares pedregosos (tejtetaj) abundam (27 topônimos), enquanto que, mais abaixo, estão as áreas de terra boa (talpan, "sobre a terra" - nove topônimos), com frequência argilosa ou lamacenta (sokitaj, chichilsokitaj, "lugar de barro [vermelho]"). Algumas áreas são mais secas (taluakpan) devido, muitas vezes, à forte inclinação. Mais ao norte, o solo é arenoso (xaltal, "areia-terra"). As terras banhadas pelos rios são consideradas permanentemente úmidas (atal, "água-terra") e "frias", enquanto que os areais do norte (xallomaj, "areia-lombada") têm uma reputação de "quentes", devido tanto ao calor que impera como ao solo que absorve a chuva rapidamente.

Outros lugares são definidos pelo tipo de vegetação. O nome genérico (kuoujtaj, "lugar de árvores") também designa, de maneira geral, o espaço desabitado, seja cultivado (o rancho) ou selvagem, por oposição as povoados (xolal). Distingue-se a floresta primária (kuoujijtik, "o interior das árvores") dos chaparrais (tapachiuis) e dos terrenos cobertos por ervas (xiujtaj, xiujkaual). As transformações introduzidas pelo homem servem também de referência: elas podem ser permanentes, como no caso dos cafezais (kajfentaj), das plantações de cana-de-açúcar (ouataj) e das pastagens (ixtauat), ou temporárias, como os milharais (milaj) e os campos de feijão (etaj). Muitos topônimos especificam, inclusive, as espécies vegetais ou animais selvagens que existem ou existiram em determinados lugares. Encontramos 47 referências à flora. Em contraste, apenas nove topônimos fazem referência à fauna: a sua mobilidade não permite associá-la facilmente a um nicho ecológico particular, exceto alguns sapos, quelônios e morcegos. Os topônimos desta última classificação são de caráter alusivo: Tekuanko ("lugar do jaguar") é um lugar onde certa vez se viu um jaguar; enquanto no Tsikatal ("terra de formigas de fogo"), a terra guarda semelhança com os formigueiros. 
Um conjunto final de categorias se refere a um espaço que é, ao mesmo tempo, o resultado permanente e o marco da ação humana, ou seja, é o próprio povoado (xolal). O espaço habitado (xolalpan, "no povo") é dividido em dois. De um lado, está o espaço público, que inclui a fonte (apan), a rua (ojti, kayej), a igreja (tiopan), o palácio municipal (palasioj), a escola (tamachtiloyan), a praça principal (palasiojtenoj) e o átrio da igreja (tiopantenoj), onde foram agregados a quadra de basquete (kanchaj), a loja cooperativa (koperativaj) e o moinho de milho (molinoj). A este espaço público se opõe o espaço privado delimitado pela casa (kali) e o terreno adjacente. Pelo lado da rua (kaltenoj, "boca da casa"), comunica-se com o espaço público. Dentro da casa, em frente à porta de entrada, o altar doméstico protege os habitantes das forças malignas. O quintal (kaltsintaj, "ânus da casa") é estritamente reservado aos membros do grupo doméstico, assim como a cozinha, onde se encontra o fogão (tikontenoj, "na boca da panela do fogo").

Os conhecimentos de topografia e solo têm consequências práticas imediatas. Com relação à agricultura, sua principal forma de interação com a natureza, os camponeses avaliam com precisão o potencial dos diferentes solos, tanto em termos de suas propriedades físicas (arenosos, argilosos, rochosos ...), como de inclinação e de altura. Eles sabem que o café cresce bem nas encostas rochosas das montanhas. O milho prefere as terras planas e encostas, mas também cresce nas colinas arenosas do norte. No entanto, ali a colheita do milho na primavera (tonalmil) será perdida se a estação seca se prolongar. Nesses locais vale mais plantar nas depressões úmidas (tauakal) ou nos espaços das cavidades (tatekoch). O feijão é mais exigente, necessita de uma terra com vários anos de barbecho e a queima do mato (tajsol) antes do plantio, para enriquecer o solo. Além disso, os cafezais e as árvores frutíferas prosperam ao abrigo das geadas esporádicas que atingem as terras mais ao sul.

Também são localizados com precisão os recursos de maior importância cultural como a malva (xonokuouit, Heliocarpus sp.), cuja casca proporciona as fibras para tecer cestos; os tanques abundantes em peixes; a água de diferentes fontes e qualidades; em determinados locais são encontradas boas pedras de amolar (tajchiktet) ou um monte cuja pedra é apropriada para uso na sauna (temaskal).

A apropriação simbólica do território implica uma dimensão onomástica particular: tradicionalmente, é a terra que dá nome ao povo. Assim, os habitantes de Kuomaytaj ("onde cresce o [espécie localmente conhecida como] cuamaite") são os Kuomaymej; um homem que cultivava em Kapoltitan ("abaixo da clidemia" - Clidemia spp.) era chamado Pedro Kapol. Listamos doze desses “nomes residenciais". Transmitidos, sobretudo, pela linha paterna, devido à residência preferencial ser patrilocal, parece que foram amplamente utilizados até o início do século XX, antes de serem substituídos por patronímicos legais. Vários permaneceram como apelidos. Por outro lado, alguns antropônimos foram convertidos em nomes de lugares: Aguilarko ("lugar dos Aguilar", Pelonko ("lugar do calvo"), etc. No entanto, existe uma clara hierarquia entre as duas formas de derivar nomes. Como dizia um interlocutor: "Chamamos [este lugar] Aguilarko porque aqui vivem os Aguilar, mas o nome da terra é Chilkuoujtaj ("lugar de chilkuouit" - Picramnia Antidesma Swarz)".

A terra é ao mesmo tempo encantada. Tanto a montanha como o rio têm uma profunda dimensão mágicoreligiosa. As cavernas ou "casas de pedra" (tekal) da montanha são as moradas dos ogros e gnomos (masakamej, 
tepeuanimej) que castigam os humanos. Elas também são consideradas como as entradas para o mundo subterrâneo de onde provêm toda a vida (Talokan) e o mundo dos mortos (Miktan). Os moradores sabem os caminhos onde aparecem as almas dos que morreram de forma violenta. As águas estão particularmente carregadas de influências sobrenaturais. Por exemplo, as lagoas são vigiadas pela "serpente com crinas"(Kuesalkouat); se ela se vai, a lagoa seca. No rio Tozán, existe um ramal de "água brilhante" (Ixpepetaniat) "lugar de [onde saem] raios" (Kioujteyojko) antes das tempestades; em outro ramal, chamada “água feiticeira” (Naualat), a água atrai o caminhante temeroso. Acima de tudo, as águas são perigosas à noite, nas proximidades de grandes rios, onde vagueiam as almas dos afogados e das crianças mortas de "susto de água" (anemoujtil). Pois, assim como o contato brusco com os elementos naturais (a água, a terra, o fogo e o ar), o encontro com os seres sobrenaturais provoca susto ou assombro (nemoujtil). O susto deixa doente, podendo levar a perder a razão e até causar a morte, ao menos que um curandeiro competente quebre o feitiço (Beaucage e Taller de Tradición Oral, 2013, cap. 6). Enquanto os campos e as florestas são relativamente seguros durante o dia, à noite, é melhor ficar na aldeia e, de preferência, em casa, protegido pelas imagens do altar doméstico.

Essa extrema riqueza toponímica, que reflete as múltiplas apropriações do território, teve um impacto político e agrário após 1870, quando foram aplicadas as leis da Reforma (1856) no território mexicano, já mencionadas, com as quais os liberais vitoriosos suprimiram a posse comunal da terra, própria das comunidades indígenas. Vimos como os Nahua de Cuetzalan primeiramente se rebelaram contra a privatização das terras comunais. Depois seguiram as recomendações de Lucas e Dieguillo e registraram individualmente as parcelas que cultivavam. Ainda são encontrados, nos arquivos locais, cadernos cheios dessas “denúncias”, com os nomes de seus proprietários, o tamanho, os limites, eo nome nahua do lugar. $\mathrm{O}$ poder de nomear suas terras foi um elemento-chave que assegurou a sua posse definitiva sob o novo regime agrário.

Os dados que acabamos de apresentar revelam a construção de um povo, os Nahua de Cuetzalán, que formou ao longo de cinco séculos uma identidade não apenas forte, mas vitoriosa. Forte porque suas práticas ecológicas, políticas e simbólicas desembocaram na apropriação material e simbólica do território claramente identificado, que corresponde às fronteiras do município atual. Este está geograficamente bem delimitado pelas canhadas abruptas de Tozan e de Apulco, ao oeste e leste, que se juntam ao norte, e pela montanha de Xocoyolo, ao sul. Essa identidade histórica é também vitoriosa: os relatos orais não nos contam uma história de vítimas, mas de "merecedores". De acordo com a memória coletiva, os indígenas cuetzaltecos venceram aqueles que quiseram submetê-los: sucessivamente, os espanhóis, os franceses e os "villistas" que assolaram a região nos anos da Revolução. Essa é a identidade que nos permite compreender o seu comportamento coletivo no período que se inicia a partir dos anos 1970.

\section{O “NOVO DESPERTAR INDÍGENA" NA SERRA NORTE DE PUEBLA}

Numerosos autores têm analisado como se consolidaram nas Américas, durante as três últimas décadas do século passado, um movimento social indígena de novo cunho (Bonfil Batalla, 1981; Warren, 1998; Stavenhagen, 2002; Ruíz Hernández e Burguete Cal y Mayor 2003; Beaucage, 2008). As “rebeliões indígenas”, que marcaram o 
período colonial, e as repúblicas depois de sua independência foram sucedidas por movimentos indígenas que logo ultrapassaram o cenário regional para adquirir dimensão nacional e até mesmo internacional. Contribuíram para isso novos atores indígenas, em particular uma juventude educada através de programas governamentais que buscavam justamente acabar com as culturas indígenas! O contexto internacional da descolonização e da aceleração das comunicações permitiu uma tomada de consciência do colonialismo interno que se estava vivendo nas Américas e a troca de experiências entre os ativistas, que vivem na floresta amazônica ou nas terras altas dos Andes e da Mesoamérica. Atores não indígenas também contribuíram, como religiosos católicos da Teologia da Libertação, assim como jovens profissionais progressistas, ambos motivados por um afã de justiça social.

Na Serra Norte de Puebla também aconteceu esse "despertar", com duas vertentes principais. Na década de 1960, freiras e padres começaram uma obra religiosa e social, formando catequistas em diversas comunidades. O resultado foi um movimento ao mesmo tempo religioso e etnopolítico, que culminou com a criação da Organização Independente Totonaco (OIT), que chegou ao poder em 1991, na cidade de Huehuetla, baluarte da cacicado regional. A OIT manteve-se na administração municipal até 1999. Depois, voltou ao poder o Partido Revolucionário Institucional (Hernández García, 2009; Ribadeneyra Morales, 2012). Sua base local foi desarticulada, mas foi criada, em 2000, uma organização regional, a Unidade Totonaco Nahua (UNITONA) com uma orientação similar. Essa vertente do movimento regional se estendeu, essencialmente, noterritório totonaco, embora esteja presente em comunidades nahua, através da Organização Independente Ahuacateca, mais ao norte, e da PRADE A.C., em San Miguel Tzinacapan (Cuetzalan).

Em Cuetzalan, surgiu nos anos 1970 um forte movimento social de protesto contra a subordinação econômica, política e cultural dos camponeses indígenas à burguesia comerciante da sede (Beaucage e Taller de Tradición Oral, 2013, cap. 2). De um lado, leigos e religiosos ligados à Teologia da Libertação deram início a grupos de cooperação econômica e de serviços (saúde, educação, cultura), no povoado de San Miguel Tzinacapan (Sánchez Almeida, 2005). No entanto, o movimento adotou como sua principal forma uma cooperativa regional, Tosepan Titataniske (“juntos venceremos"), apoiada por uma rede de cooperativas locais. Durante vários anos, a Tosepan foi dedicada principalmente à comercialização de produtos agrícolas (pimenta, café) e o fornecimento de grãos básicos, transpondo o sistema tradicional de intermediários da sede (Aguilar Ayón e Mora, 1991). O trabalho de conscientização colocou mais ênfase na condição camponesa do que na identidade cultural. Para as bases Nahua, a Tosepan rapidamente se tornou o principal instrumento de defesa e promoção social e étnica. A cooperativa adentrou brevemente no campo da política municipal e conseguiu que seu candidato ("o candidato dos ranchos") e um grupo de vereadores fossem eleitos para a administração municipal. Apesar do grande valor simbólico que marcou a eleição do primeiro prefeito indígena desde Palagosti Dieguillo, a experiência não foi considerada um sucesso, em parte por causa do boicote econômico que o município sofreu das autoridades estaduais, e o PRI voltou ao poder em 1990. Nos anos seguintes, a organização optou por pressionar de fora as autoridades eleitas.

Na década de 1980, a retirada do Estado de sua ação no campo em favor do livre mercado afetou diretamente 
as organizações camponesas, incluindo a Tosepan, que já não podia contar com créditos e garantias de preços. A organização perdeu a maioria de seus assessores, mas já havia formado quadros indígenas locais para realizar suas funções. A cooperativa regional conseguiu preservar e expandir sua base social. Em 1999, para responder à crescente integração da região na economia monetária, foi criada uma cooperativa de poupança e crédito, Tosepan Tomin, através da qual aumentou o número de membros para mais de vinte mil, incluindo as várias comunidades totonaco. Com esta abertura, pela primeira vez, o espaço da organização já não correspondia ao território nahua de Cuetzalan. Nas décadas anteriores, a "indianização" da cooperativa significava sua "nahuatização", evidenciada tanto em termos de nomenclatura (Kaltaixpetaniloyan, Tosepan Xikaualis etc.), como pela língua de trabalho das cooperativas central e locais. Os novos membros Totonaco não veem ainda refletida na organização sua própria identidade étnica.

Durante as mesmas décadas, foram criadas outras organizações no município, como uma sociedade de artesãs (Maseualsiuamej Sentekitinij, em 1986), um grupo de direitos humanos(Takachiualis, em 1990) e um Juizado Indígena autônomo (em 2002).

Tanto os Nahua como os Totonaco do nordeste da Serra desenvolveram, seguindo regras e temporalidades próprias, duas vertentes de um movimento camponês indígena regional. Enraizados em um território municipal, a OIT e a Tosepan conseguiram contrapor-se ao monopólio econômico e político da burguesia local (sem eliminá-lo). Ambas desembocaram na necessidade de ampliar a organização indígena além de seus núcleos territoriais de origem, Cuetzalan e Huehuetla.

\section{UMA NOVA CONJUNTURA: OS MEGAPROJETOS}

Em 2009, foi apresentado um plano da Secretaria de Turismo do Estado de Puebla, que pretendia transformar Cuetzalan em um destino de turismo de massa, com projeções de até duzentos mil turistas ao ano. Tal projeto implicaria em investimentos maciços em infraestrutura, incluindo a construção de uma nova estrada entre a serra e a costa, atravessando a cidade. Ao mesmo tempo, a transnacional Walmart, já fortemente estabelecida no México, anunciou a instalação de uma sucursal em Cuetzalan. A Tosepan e outras organizações rapidamente formaram o Comitê de Ordenamento Ecológico Territorial Integral de Cuetzalan (CORDETIC), expondo uma alternativa própria: o desenvolvimento equilibrado entre a agricultura, o artesanato e o ecoturismo, que já tinha bases locais. No comércio, o mercado indígena semanal e as lojas seriam suficientes. Além disso, a Tosepan Titataniske e o grupo de artesãs Maseualsiuamej tinham, cada um, um espaço onde promoveriam o conhecimento da cultura local e o respeito ao meio ambiente. Graças a essa rápida resposta, o megaprojeto turístico foi suspenso e Walmart renunciou a implantação em Cuetzalan. A força e a eficácia das organizações não podem ser compreendidas sem levar em conta os processos históricos que temos esboçado.

Em 2010, os habitantes da serra nordeste souberam que o governo federal havia outorgado concessões "para a exploração e a prospecção" mineral em sete municípios da zona alta , totalizando 56 mil hectares. No total, entre 2006 e 2008, foram outorgadas 85 concessões, das quais cerca de 20 seguem explorando até hoje. A Serra Norte de Puebla 
não é um caso isolado: outras regiões do México e da América Latina são objeto de uma verdadeira ofensiva por parte de empresas minerárias, muitas delas canadenses . Essa ofensiva responde à demanda por metais e minerais não-metálicos, incrementada bem depois do ano 2000, sob o efeito combinado do crescimento asiático (ávido por metais industriais como o cobre, ferro...) e a crise das economias ocidentais que incita os mais ricos a buscar valores seguros como o ouro. Desde 1992, as empresas de mineração desfrutam, no México, de um contexto legal plenamente favorável, após as mudanças introduzidas pelo governo de Carlos Salinas de Gortari: a Nova Lei de Mineração(1992), em seu artigo $6^{\circ}$, estabelece que "a exploração, a prospecção e processamento de minerais" terá precedência sobre qualquer outra forma de utilização ou valorização do terreno.

Para explorar os recursos minerais da serra alta, empresas como Frisco (de propriedade de Carlos Slim, "o homem mais rico do mundo") contam com o abastecimento de água em reservatórios locais dessa região semiárida. Também precisam de uma grande quantidade de eletricidade para triturar e centrifugar o mineral. Daí a sua decisão de produzir sua própria eletricidade através da construção de barragens nos rios caudalosos da serra baixa, em território totonaco. Desde abril de 2011, o Grupo México (de propriedade do multimilionário Germán Larrea) obteve do governador de Puebla uma permissão para construir três barragens no rio Ajajalpan, em território totonaco, e duas, no rio Apulco. Seus agentes, junto aos da consultoria Comexco, pressionam os totonaco ribeirinhos a venderem suas terras.

Informados dos desastres ambientais que a mineração a céu aberto e as barragens têm produzido em outras partes do México, os habitantes de três municípios particularmente afetados organizaram protestos. Os vizinhos de Tetela de Ocampo, onde a mineradora Frisco quer extrair ouro e prata, formaram a Tetela Para o Futuro, uma coalizão que se opõe a qualquer entrada de mineradoras no município. Regionalmente, a UNITONA, a Tosepan Titataniske e outras organizações uniram seus esforços em uma organização regional, o Conselho Tiyat Tlalli , para enfrentar essa nova ameaça.

O perigo existe. Na cidade vizinha de Zautla, aAlmaden Minerals, uma das principais mineradoras canadenses no México, detectou ouro e prata. Ali foi formada uma vasta coalizão de organizações populares, formada por grupos que vão dos artesãos aos produtores orgânicos. Eles se opuseram ao projeto, apesar dos presentes oferecidos por Almaden aos vizinhos de Tlamanca a fim de suborná-los. Almaden vendeu então seus títulos a uma empresa de mineração chinesa, a JDC Minerais. Esta não poderia imaginar onde tinha se metido: as licenças de exploração eram inválidas ou inexistentes. Finalmente, em 22 de novembro de 2012, quando o ultimato imposto à JDC expirou, mais de cinco mil camponeses marcharam sobre a mina. Arrancaram a cerca de proteção e expulsaram os dirigentes e os trabalhadores chineses (Beaucage, 2013).

Em 6 de outubro de 2012, em Zapotitlán de Méndez, aldeia Totonaco situada nas margens do rio Zempoala, mil moradores reunidos em assembleia se opuseram ao projeto hidrelétrico de Ingdeshidro. Convidada a apresentar seu projeto, a empresa, que já está comprando terrenos, nunca chegou. Em meados de dezembro de 2012, em Olintla, onde se quer construir outra barragem, os camponeses Totonaco da comunidade de Ignacio Zaragoza, bloquearam o 
acesso e sequestraram as máquinas. Apoiados por outros integrantes de Tiyat Tlalli, mantiveram o bloqueio por um mês, apesar da repressão coordenada pelas autoridades mestiças do município. Mesmo que ainda não sejam afetados diretamente, os cuetzaltecos participam de ações conjuntas porque sabem que, mais cedo ou mais tarde, verão suas terras inundadas ou receberão em suas águas os resíduos de mineração contaminados com cianeto.

\section{CONCLUSÃO}

Hoje, pela primeira vez na história, a defesa do território e da água está unindo, no Conselho Tiyat Tlalli, os camponeses indígenas Nahua e Totonaco, da serra alta e da serra baixa. Eles procuram fazer frente aos megaprojetos de mineração e hidrelétricos através de assembleias informativas e da ação direta como ocorreu em Olintla.

Essas ações são baseadas em processos históricos antigos e recentes de formação de identidade e do território, como a apropriação simbólica das terras comunitárias pormeio da toponímia, estreitamente relacionada com a memória coletiva, que apresentamos brevemente no caso de Cuetzalan. Também se baseiam na construção de organizações indígenas autônomas, que nasceram em torno de objetivos econômicos ou políticos locais e que agora estão expandindo sua ação frente a novos desafios. Essa expansão também supõe uma mudança na visão do território. A partir do ano 2000, pela primeira vez desde que se uniram contra os invasores franceses, em meados do século XIX, as organizações indígenas ultrapassaram o marco comunitário e municipal onde haviam situados suas lutas ao longo do século XX. A Tosepan expandiu sua ação cooperativa para a região totonaco e a OIT criou a UNITONA para incluir os Nahua. Até que as duas vertentes se uniram no Conselho Tiyat Tlalli.

A estratégia atual das organizações e dos povos afetados pela mineração e pelas hidrelétricas é impedir a instalação das empresas. Para isso, contam, sobretudo, com sua coesão, particularmente forte nas comunidades indígenas. E eles sabem que nessa luta desigual podem contar com instrumentos legais, como a Convenção 169 da Organização Internacional do Trabalho e a Declaração sobre os Direitos dos Povos Indígenas das Nações Unidas. Ambos os documentos, ratificados pelo governo mexicano, insistem sobre a necessidade da consulta prévia e informada dos povos indígenas antes de implementar megaprojetos em seus territórios. As organizações da serra nordeste não hesitam em associar-se com estudiosos contra as instâncias governamentais e judiciais. E a consciência de suas vitórias passadas reforça sua determinação.

Versão em português: Clarissa Tavares

\section{BIBLIOGRAFIA}

AGUILARAYÓN,A.eS. MORA, 1991 :Participación dela CooperativaAgropecuaria Regional Tosepan Titataniske en la estructura regional de poder y su influencia en el desarrollo rural. El caso de la región de Cuetzalan, Sierra Norte de Puebla. Mexico. Mexico, Universidad Autónoma Metropolitana-Xochimilco (tesis de maestría). 
ARQUIVO HISTÓRICO MUNICIPAL DE CUETZALAN, Cuetzalan, Puebla (investigado em 1989-1991).

ARQUIVO HISTÓRICO DE SAN MIGUEL TZINACAPAN, Cuetzalan, Puebla (investigado em 1989-1991).

ARQUIVO DAPARÓQUIADE SAN FRANCISCO, LIVRO DE BATISMOS. Cuetzalan, Puebal (consultado em 1969).

BEAUCAGE, Pierre, 1974: “Comunidades indígenas de la Sierra Norte de Puebla”, Revista mexicana de sociología, Vol. 36, (no 1): 11-147.

, 1976 : "Etnohistoria y marxismo: una región periférica del imperio azteca" Nueva Antropología, Vol 1 (no 4): 43-82.

, 1995 : "Ethnies et société: deux ethnohistoires des Nahuas (Sierra Norte de Puebla)" in La construction de l'anthropologieau Québec. Enhommageà M.A. Tremblay (P. CharestetF. Trudel, dir.) Québec, Presses de l'Université Laval : 337-366.

, 2008 : «Los imaginarios de la indianidad hoy. Diversidad y convergencia » Versión. Estudios de comunicación y política. Universidad Autónoma Metropolitana (Mexico) (Número temático : Comunicación : Imaginarios y representaciones sociales) (19) : 45-73.

_ 2013 : “Mexique : résistance populaire face aux minières canadiennes”, À Babord! (48) : 34-36.

BEAUCAGE, Pierre e TALLER DE TRADICIÓN ORAL, 2013 : Cuerpo, cosmos y medio ambiente entre los nahuas de la Sierra Norte de Puebla. Una aventura en antropología. México, Plaza y Valdés (en prensa).

BONFIL BATALLA, Guillermo, dir., 1981 : Utopía y revolución. El pensamiento contemporáneo de los indios en América Latina. Mexico, Nueva Imagen.

BUSTAMANTEPEÑA, Gabriel,2012 :Elderechoala consulta previa.Avancesy retos enAméricaLatina.Asociación Latinoamericana de Organizaciones de Promoción al Desarrrollo(ALOP), Cuadernos de Debate\#1. (Doc. electrónico : http://www.redextractivas.org/images/publicaciones/Conflictos/cuadernos.

CORDETIC(COMITÉDEORDENAMIENTOECOLÓGICOTERRITORIALINTEGRALDECUETZALAN), 2010 : Programa de ordenamiento ecológico local del territorio del Municipio de Cuetzalan. Cuetzalan, 15 de octubre 2010.

DENAULT, Alain e William SACHER, 2012 : Le paradis sous terre. Comment le Canada est devenu la plaque tournante de l'industrie minière mondiale. ['El paraíso bajo tierra. Como Canadá se convirtió en la pieza clave de la industria minera mundial'] Montréal, Écosociété. 
De la MOTAe ESCOBAR, Alonso (1609-1624) 1940: “Memoriales del Obispo de Tlaxcala, Fray Alonso de la Mota y Escobar. Visitas 1609-1624” Anales del Instituto Nacional de Antropología e Historia. Tomo 1, p. 191-306.

GARCÍA MARTÍNEZ, Bernardo. 1987 : Los pueblos de la Sierra. El poder y el espacio entre los indios del norte de Puebla hasta 1700. Mexico, El Colegio de México.

GARCÍA PAYÓN, J. (dir.) Descripción del Pueblo de Gueytlalpan por el alcalde mayor Juan de Carrión (1581). Xalapa, Universidad Veracruzana (Cuadernos de Filosofia No 23).

GARIBAY, Claudio, Andrew BONI, Dan KLOOSTER, Francesco PANICO e Pedro URQUIJO, 2011 : “Unequal Partners, Unequal Exchange : Goldcorp, the Mexican State and Campesino Disposession at Peñasquito Goldmine" Journal of Latin American Geography, Vol. 10 (2) p. 153-176

GIBSON, Charles, 1964 : The Aztecs under Spanish Rule : A History of the Indians of the Valley of Mexico. (15191810). Standford, Standford University Press.

GONZÁLEZ, Juan (1581) 1905: "Relación de Xonotla y Tetela” in Papeles de Nueva España (Francisco Paso y Troncoso, ed.) Madrid, Gobierno Mexicano, Vol. 5, p. 124-173.

HERNÁNDEZGARCÍA, Milton Gabriel, 2009 : Kali akgwahu kin tiyatkan, kali agkwahu kin kuxi kan(Defendamos nuestra tierra, defendamos nuestro maíz). Los caminos de la resistencia indígena en la Sierra Norte de Puebla. (Tesis de licenciatura en México), México, Escuela Nacional de Antropología e Historia.

JÁIMEZ, G, C. RÁMIREZ e P. VALDERRAMA, 1992 : Tijuan titalnamikij... Nosotros recordamos le pasado. Puebla, Gobierno del Estado de Puebla, Secretaría de Cultura (Comisión Puebla V Centenario).

JORNADA DEL CAMPO, 2013 : Tierra abrasada. Supl. de La Jornada 6(67), 20 de abril.

PALAFOX y MENDOZA, Juan (1643-1646) : Relación de las visitas que realizó el ilustrísimo y excelentiísimo obispo de la Puebla de los Ángeles don Juna Palafox y Mendoza (Juan Manual Pérez Zevallos, ed.) Madrid, Biblioteca Naional, ms 4476.

PARÉ, Luisa, 1975 : “Caciquismo y estructura de poder en la Sierra Norte de Puebla” in Caciquismo y poder político en el México rural (R. Bartra et al.). México, Siglo XXI: 31-61.

SÁNCHEZ, María Eugenia e Eduardo ALMEIDA, 2005 : Las veredas de la incertidumbre. Relaciones interculturales y supervivencia digna. Puebla, Univerdidad Iberoamericana.

TALLER DE TRADICIÓN ORAL del CEPEC, 1994 : Tejuan tikintenkaliliayaj toueytatajuan... / Les oíamos contar a los abuelos. Etnohistoria de San Miguel Tzinacapan. Pue. México, InstitutoNAH. 
TALLER DE TRADICIÓN ORAL del CEPEC y Pierre BEAUCAGE, 1987 : Catégories pratiques et taxonomie: notes sur les classifications et les pratiques botaniques des Nahuas (Sierra Norte de Puebla (Mexique)" Recherches Amérindiennes au Québec, Vol. 17 (no 4), p. 17-36.

, 1995 : "Ethnies et société: deux ethnohistoires des Nahuas (Sierra Norte de Puebla)" in La construction de l'anthropologie au Québec. Enhommageà M.A. Tremblay (P. CharestetF. Trudel, dir.) Québec, Presses de l'Université Laval : 337-366.

, 1997a: "The Traditional Indian Coffee Orchard of Eastern Mexico” Journal of Ethnobiology, Vol. 17 (no 1), p. 45-68

_, 1997b : 'La bonne montagne et l'eau malfaisante. Toponymie et pratiques environnementales chez les Nahuas de basse montagne (Sierra Norte de Puebla (Mexique) “Anthropologie et Sociétés, Vol 20 (3) : 33-54.

TALLER DE TRADICIÓN ORAL del CEPEC y Pierre BEAUCAGE, 2003 : “La mujer el oso y la serpiente en dos mitos nahuas". Cuadernos del Sur, Vol. 9 (no 19), p. 59-74.

THOMSON, Guy P.C., 1991 : "Agrarian Conflict in the Municipality of Cuetzalan (Sierra de Puebla) : the Rise and Fall of Pala Agustín Dieguillo 1861-1894” Hispanic American Historical Review, Vol 71, no 2 p. 205-258.

THOMSON, Guy P.C., 1999 : Town histories, military memoirs and recent oral accounts of the European Intervention in the Sierra de Puebla, 1868-1991. (Conferencia presentada en el congreso del American Historical Institute for Latin America, Oporto [Portugal] 21-25 de septiembre) ms

THOMSON, Guy P.C. e David G. LA FRANCE 1999 : Patriotism, Politics and Popular Liberalism in NineteenthCentury Mexico. Juan Franciso Lucas and the Puebla Sierra. Wilmington(Delaware), Scholarly Resources.

VOCES DE ALERTA, 2011. 15 mitos y realidades de la minería transnacional en la Argentina. Buenos Aires, Herramientas Ediciones, Editorial El Colectivo, Colección Cascotazos.

WARREN, Kay, 1998 : Indigenous Movements and Their Critics. Pan Maya Activism in Guatemala. Princeton, Princeton University Press. 